\title{
Clinical evolution of cases of COVID-19 infection in neopediatrics: a scoping review
}

\author{
Evolução clínica dos casos de infecção por COVID-19 em neopediatria: scoping review \\ Evolución clínica de los casos de infección por COVID-19 en neopediatría: scoping review
}

Thatiane Monick de Souza Costa' ORCID: 0000-0002-8827-9653

Kauanny Vitoria Gurgel do Santos' ORCID: 0000-0003-4679-1840

Rodrigo Rhuan Andrade Rocha' ORCID: 0000-0002-3487-5230

Eloysa dos Santos Oliveira' ORCID: 0000-0001-9635-3668

Rodrigo Assis Neves Dantas' ORCID: 0000-0002-9309-2092

Daniele Vieira Dantas' ORCID: 0000-0003-0307-2424

'Universidade Federal do Rio Grande do Norte. Natal, Rio Grande do Norte, Brazil.

How to cite this article: Costa TMS, Santos KVG, Rocha RRA, Oliveira ES, Dantas RAN Dantas DV. Clinical evolution of cases of COVID-19 infection

in neopediatrics: a scoping review. Rev Bras Enferm. 2021;74(Suppl 1):e20200662. doi: http://dx.doi.org/10.1590/0034-7167-2020-0662

Corresponding author:

Daniele Vieira Dantas E-mail: daniele00@hotmail.com

EDITOR IN CHIEF: Dulce Barbosa ASSOCIATE EDITOR: Priscilla Broca

Submission: 06-15-2020

Approval: 10-31-2020

\section{ABSTRACT}

Objective: to map the knowledge about the clinical findings, treatment and outcome of newborns and children infected with COVID-19. Methods: a scoping review with search of eight databases and electronic search engine in April 2020. Results: the 12 studies analyzed showed that the main clinical findings in this population were nasal congestion, fever, respiratory distress, diarrhea, fatigue, dry cough, increased C-reactive protein, leukopenia, lymphopenia, thrombocytopenia, elevated procalcitonin, bilateral groundglass opacity, pulmonary consolidation, and pneumonia. Antivirals, respiratory support, immunomodulatory therapy, glucocorticoids, antibiotics and alpha interferon were used as treatment. The presence of a cure with hospital discharge is present in most cases. Final considerations: most patients required hospitalization, but it evolved to cure. This study provided a greater scientific basis by showing clinical findings, treatment, and outcomes in neopediatric patients with COVID-19.

Descriptors: Coronavirus; Newborn; Pediatrics; Clinical Evolution; Infections.

\section{RESUMO}

Objetivo: mapear o conhecimento acerca dos achados clínicos, tratamento e desfecho de recém-nascidos e crianças infectadas por COVID-19. Métodos: revisão de escopo que realizou busca em oito bases de dados e em buscador eletrônico no mês de abril de 2020. Resultados: os 12 estudos analisados mostraram que os principais achados clínicos nessa população foram congestão nasal, febre, desconforto respiratório, diarreia, fadiga, tosse seca, aumento da proteína C reativa, leucopenia, linfopenia, plaquetopenia, elevação da procalcitonina, opacidade bilateral em vidro fosco, consolidação pulmonar e pneumonia. Como tratamento, foram utilizados os antivirais, suporte respiratório, terapia imunomoduladora, glicocorticoides, antibióticos e interferon alfa. A presença da cura com alta hospitalar se faz presente na maioria dos casos. Considerações finais: a maioria dos pacientes necessitou de internamento, porém evoluiu para cura. Este estudo possibilitou maior embasamento científico ao mostrar achados clínicos, tratamento e desfechos em pacientes neopediátricos com COVID-19.

Descritores: Coronavirus; Recém-Nascido; Pediatria; Evolução Clínica; Infecções.

\section{RESUMEN}

Objetivo: mapear el conocimiento sobre los hallazgos clínicos, el tratamiento y la evolución de los recién nacidos y niños infectados por COVID-19. Métodos: scoping review realizada en ocho bases de datos y en un motor de búsqueda electrónico en abril de 2020. Resultados: los 12 estudios analizados mostraron que los principales hallazgos clínicos en esta población fueron congestión nasal, fiebre, dificultad respiratoria, diarrea, fatiga, tos seca, aumento de proteína $\mathrm{C}$ reactiva, leucopenia, linfopenia, trombocitopenia, procalcitonina elevada, opacidad vítrea bilateral mate, consolidación pulmonar y neumonía. Como tratamiento se utilizaron antivirales, soporte respiratorio, terapia inmunomoduladora, glucocorticoides, antibióticos e interferón alfa. La presencia de una cura con el alta hospitalaria está presente en la mayoría de los casos. Consideraciones finales: la mayoría de los pacientes requirieron hospitalización, pero evolucionaron hasta curarse. Este estudio proporcionó una mayor base científica al mostrar los hallazgos clínicos, el tratamiento y los resultados en pacientes neopediatricos con COVID-19.

Descriptores: Coronavirus; Recién Nacido; Pediatría; Evolución Clínica; Infecciones. 


\section{INTRODUCTION}

Coronaviruses are a vast family of viruses that affect humans and can cause a series of pathological conditions of lesser or greater severity. These viruses can range from a common cold to more serious illnesses and affect any system in the body. The most well-known diseases resulting from coronaviruses are the Middle East Respiratory Syndrome (MERS-CoV) and the Severe Acute Respiratory Syndrome (SARS-CoV-2)(1).

In late December 2019, the Chinese Center for Disease Control and Prevention accompanied the health authorities in Wuhan, conducting an epidemiological and etiological investigation into pneumonia cases of unknown etiology. A new coronavirus (2019$\mathrm{nCoV}$ ) was found that was identified in hospitalized patients in December 2019 and January 2020(2).

The Coronavirus Study Group (CSG) of the International Committee on Virus Taxonomy named the "new coronavirus" of coronavirus 2, associated with SARS-CoV-2 ${ }^{(3)}$.

Transmission by SARS-CoV-2 is considerably higher than by other viruses. Therefore, its mortality rate is higher due to its rapid transmissibility and ability to generate severe lung injury ${ }^{(4)}$.

In pediatric patients, the disease onset varies according to age between 1.5 months to 17 years old, and infected children may be asymptomatic or have mild clinical manifestations such as fever, dry cough, and fatigue. A few have symptoms of the upper respiratory tract such as nasal congestion and rhinorrhea, in addition to gastrointestinal changes, including nausea, vomiting, abdominal discomfort or pain and diarrhea(5-6).

Treatment varies according to patients' needs. Suspects must be isolated in a single room, or at home, for 14 days, following the guidelines of health professionals. Confirmed cases can be admitted to the same ward. Critical cases, on the other hand, must be admitted to Intensive Care Units (ICUs) ${ }^{(6)}$.

Prevention occurs through practices to control sources of infection through social isolation of infected children, with a single room, cleaning and disinfecting objects with $75 \%$ alcohol or chlorine, blocking transmission routes from hand washing with use of the correct technique, use of napkins to cover mouth and nose when coughing or sneezing, use of a mask in public places and susceptible population protection ${ }^{(6)}$.

Transmission among humans occurs through contact with an infected person through coughing, sneezing, droplets or aerosols. Aerosols can reach the lungs with the nose or mouth as a gateway ${ }^{(7)}$. It also occurs through contact with objects (fomites) or contaminated surfaces, and, shortly thereafter, an individual touches his or her mouth, nose or eyes ${ }^{(8-9)}$. Another possible form of transmission occurs through contact between uninfected people and asymptomatic infected people in the same environment ${ }^{(10)}$.

Respiratory tract diseases are among the leading causes of child mortality worldwide and the largest share of these are caused by viruses ${ }^{(11)}$. Infections of the lower respiratory tract correspond to important complications when considering them responsible for $16 \%$ of infant mortality in an age group under five years ${ }^{(12)}$.

In the case of COVID-19, there is no evidence of intrauterine infection caused by vertical transmission so newborns (NBs) end up acquiring SARS-CoV-2 infection through close contact with infected mothers. In most pediatric cases, transmission occurs in a family environment, when an infected adult comes into contact with a child ${ }^{(13-14)}$.

It is important to emphasize that cases of neonatal infection caused by the virus and confirmed in the laboratory must be admitted to an ICU. If NBs have respiratory distress syndrome, high-dose pulmonary surfactant, nitric oxide inhalation and high-frequency oscillatory ventilation should be administered ${ }^{(15)}$.

The present study, the object of which is the clinical evolution of cases of COVID-19 infection in neopediatrics, is justified and important in showing a pandemic theme that is still little known and has been affecting the different age groups in large proportions, in a worrying way, due to the ease of transmission, the worsening of the clinical picture, the possibility of death and costly expenses with individual protection equipment, supplies, medications and hospitalizations. Moreover, it provides data to the scientific community regarding the main clinical findings, treatments and outcomes of NBs and pediatric patients allowing the development of more effective assistance with the possibility of resulting in more positive outcomes.

For this reason, there is a need for greater knowledge and research on the subject. Explanations/studies in literature can directly impact health actions, improving the quality of care provided.

\section{OBJECTIVE}

To map the knowledge about the clinical findings, treatment and outcome of newborns and children infected with COVID-19.

\section{METHODS}

\section{Ethical aspects}

As this is a scoping review with public domain data, it was not necessary for an Ethics Committee to review it.

\section{Type of study}

This is a scoping review used in order to identify the main evidence available on a given topic, exposing its knowledge gaps and clarify its main concepts according to literature. This research was developed according to the 2020 Joanna Briggs Institute's Review Manual recommendations ${ }^{(16)}$, and the Preferred Reporting Items for Systematic reviews and Meta-Analyzes extension for Scoping Reviews (PRISMA-ScR) was used ${ }^{(17)}$. This scoping review was recorded on the Open Science Framework platform for registering scientific papers (https://osf.io/et4p8)(18).

In order to identify and track other scoping reviews or protocols similar to the objective of this work, in April 2020, a search was carried out on the following platforms: International Prospective Register of Systematic Reviews (PROSPERO), Open Science Framework (OSF), The Cochrane Library, JBI Clinical Online Network of Evidence for Care and Therapeutics (COnNECT+), and Database of Abstracts of Reviews of Effects (DARE).

As a research strategy, Population, Concept, and Context (PCC) method was used to formulate the following research question: what is the knowledge about the clinical findings, treatment and outcome of NBs and children infected with COVID- 19? Thus, this 
review included studies that focused on: a) as a population, neonates and children; b) as a concept, the knowledge about clinical findings, treatment and outcome in neonatal and pediatric patients infected with COVID-19; c) as a context, intra and extra-hospital environment.

\section{Data source and search strategy}

Eight databases were accessed through the federated academic community on the Coordination for the Improvement of Higher Education Personnel (CAPES - Coordenação de Aperfeiçoamento de Pessoal de Nível Superior) Journal Portal, including: Cumulative Index to Nursing and Allied Health Literature (CINAHL), Cochrane Library, Latin American Literature \& Caribbean Health Sciences (LILACS), Medical Literature Analysis and Retrieval System Online (MEDLINE), SciVerse Scopus, Web of Science, Scientific Electronic Library Online (SciELO), Thesis and Dissertations Catalog. The Medical Subject Headings (MeSH) controlled descriptors used were "Coronavirus", "Infant, Newborn", and "Pediatrics", and the selected keywords were SARS-CoV-2 and COVID-19. Descriptors and keywords were crossed using the Boolean operator AND. Chart 1 addresses the search syntax adopted according to the data sources used.

Chart 1 - Search syntax in scientific data sources, 2020

\begin{tabular}{|c|c|}
\hline Data sources & Adopted syntax \\
\hline MEDLINE* & $\begin{array}{l}\text { ("Infant, Newborn" [All Fields] AND "coronavirus" } \\
\text { [All Fields]) AND ("Infant, Newborn" [All Fields] AND } \\
\text { "COVID-19" [All Fields]) AND ("Infant, Newborn" } \\
\text { [All Fields] AND "SARS-CoV-2" [All Fields]) AND } \\
\text { ("Pediatrics" [All Fields] AND"coronavirus" } \\
\text { [All Fields]) AND ("Pediatrics" [All Fields] AND } \\
\text { "COVID-19" [All Fields]) AND ("Pediatrics" [All Fields] } \\
\text { AND "SARS-CoV-2" [All Fields]) }\end{array}$ \\
\hline Scopust & $\begin{array}{l}\text { (KEY (“Infant, Newborn") AND KEY ("coronavirus")) } \\
\text { AND (KEY ("Infant, Newborn" AND TITLE-ABS- } \\
\text { KEY ("COVID-19")) AND (KEY ("Infant, Newborn") } \\
\text { AND TITLE-ABS-KEY (“SARS-CoV-2")) AND (KEY } \\
\text { (“Pediatrics") AND KEY ("coronavirus")) AND (KEY } \\
\text { ("Pediatrics") AND TITLE-ABS-KEY ("COVID-19")) } \\
\text { AND (KEY (“Pediatrics") AND TITLE-ABS-KEY } \\
\text { ("SARS-CoV-2")) }\end{array}$ \\
\hline CINAHL $\neq$ & $\begin{array}{l}\text { (Infant, Newborn AND COVID-19) AND (Infant, } \\
\text { Newborn AND coronavirus) AND (Infant, } \\
\text { Newborn AND SARS-CoV-2) AND (Pediatrics AND } \\
\text { COVID-19) AND (Pediatrics AND Coronavirus) } \\
\text { AND (Pediatrics AND SARS-CoV-2) }\end{array}$ \\
\hline $\begin{array}{c}\text { Web of } \\
\text { Science§ }\end{array}$ & $\begin{array}{l}\text { (TOPIC: (Infant, Newborn) AND TOPIC: } \\
\text { (Coronavirus)) AND (TOPIC: (Infant, Newborn) } \\
\text { AND TOPIC: (COVID-19)) AND (TOPIC: (Infant, } \\
\text { Newborn) AND TOPIC: (SARS-CoV-2)) AND (TOPIC: } \\
\text { (Pediatrics) AND TOPIC: (Coronavirus)) AND } \\
\text { (TOPIC: (Pediatrics) AND TOPIC: (COVID-19)) AND } \\
\text { (TOPIC: (Pediatrics) AND TOPIC: (SARS-CoV-2)) }\end{array}$ \\
\hline $\begin{array}{l}\text { Cochrane } \\
\text { Library\|l }\end{array}$ & $\begin{array}{l}\text { (Infant, Newborn) in Title Abstract Keyword AND } \\
\text { (Coronavirus) in Title Abstract Keyword AND } \\
\text { (Infant, Newborn) in Title Abstract Keyword AND } \\
\text { (COVID-19) in Title Abstract Keyword AND (Infant, } \\
\text { Newborn) in Title Abstract Keyword AND (SARS- } \\
\text { CoV-2) in Title Abstract Keyword AND (Pediatrics) in } \\
\text { Title Abstract Keyword AND (Coronavirus) in Title } \\
\text { Abstract Keyword AND (Pediatrics) in Title Abstract } \\
\text { Keyword AND (COVID-19) in Title Abstract Keyword } \\
\text { AND (Pediatrics) in Title Abstract Keyword AND } \\
\text { (SARS-CoV-2) in Title Abstract Keyword }\end{array}$ \\
\hline
\end{tabular}

To be continued

\begin{tabular}{|c|c|}
\hline Data sources & Adopted syntax \\
\hline LILACSף & $\begin{array}{l}\text { Infant, Newborn [Words] AND coronavirus [Words] } \\
\text { AND Infant, Newborn [Words] AND COVID-19 } \\
\text { [Words] AND Infant, Newborn [Words] AND } \\
\text { SARS-CoV-2 [Words] AND Pediatrics [Words] AND } \\
\text { Coronavirus [Words] AND Pediatrics [Words] AND } \\
\text { COVID-19 [Words] AND Pediatrics [Words] AND } \\
\text { SARS-CoV-2 [Words] }\end{array}$ \\
\hline SciELO** & $\begin{array}{l}\text { ((Infant, Newborn) AND (coronavirus)) AND } \\
\text { ((Infant, Newborn) AND (COVID-19)) AND ((Infant, } \\
\text { Newborn) AND (SARS-CoV-2)) AND ((Pediatrics) } \\
\text { AND (coronavirus)) AND ((Pediatrics) AND } \\
\text { (COVID-19)) AND ((Pediatrics) AND (SARS-CoV-2)) }\end{array}$ \\
\hline $\begin{array}{l}\text { Catalog of } \\
\text { Theses and } \\
\text { Dissertations } \\
\text { (CAPES)†† }\end{array}$ & $\begin{array}{l}\text { ("Infant, Newborn" AND "Coronavirus") AND } \\
\text { ("Infant, Newborn" AND "COVID-19") AND ("Infant, } \\
\text { Newborn" AND "SARS-CoV-2") AND ("Pediatrics" } \\
\text { AND "Coronavirus") AND ("Pediatrics" AND } \\
\text { "COVID-19") AND ("Pediatrics" AND "SARS-CoV-2") }\end{array}$ \\
\hline
\end{tabular}

Note: *MEDLINE - Medical Literature Analysis and Retrieval System Online; † Scopus - Elsevier's SCOPUS; $¥$ CINAHL - Cumulative Index of Nursing and Allied Health; $\$ W e b$ of Science; \|Cochrane Library; ILILACS-Latin American \& Caribbean Literature in Health Sciences; ** SciELO-The Scientific Electronic Library Online; +† Catalog of Theses and Dissertations (CAPES).

\section{Data collection and organization}

The search strategy was carried out in April 2020 and for the purposes of this review, literature published in any language, available in an Open Access format, without time frame and also ministerial ordinances and guidelines that addressed the clinical evolution of cases of COVID-19 infection in neopediatrics.

Articles that did not answer the guiding question, abstracts and conference proceedings were excluded from the search selection. Duplicate studies were counted only once, and repeated ones were excluded.

\section{Data analysis}

Screening the articles included in this review was analyzed by three reviewers, based on the information provided in title and abstract. When there were doubts about screening, the full version of the articles was assessed by two independent reviewers to verify whether it met the inclusion criteria to compose the final sample.

After selecting the studies, they were arranged in a structured form containing data on reference, year of publication and country, type of study, population, clinical findings, treatment, outcome and level of evidence, degree of recommendation according to Oxford Center for Evidence-Based Medicine ${ }^{(19)}$.

\section{RESULTS}

The initial search carried out in the different databases raised a total of 7,067 studies and an additional record was identified in another source. After excluding duplicate citations, titles from 1,399 studies were read, in order to see if they met the inclusion criteria. Of these, 33 records were selected for reading abstracts, and 30 studies were included for full text analysis by two independent reviewers. Of the 30 articles read in full, 20 were excluded for not responding to the objectives of the study and 10 studies were included for this review, as shown in Figure 1. Of the 10 selected records, five (50\%) came from the Scopus database, four (40\%) from Web of Science and one (10\%) from MEDLINE. 


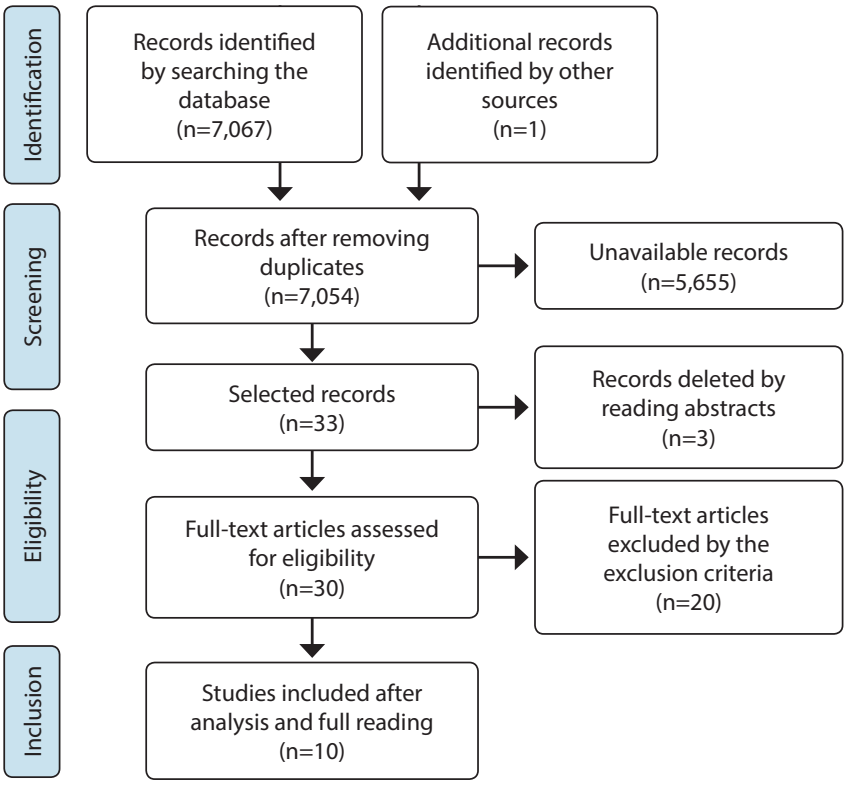

Figure 1 - Flow diagram PRISMA-ScR, 2020
Chart 2 presents a summary of the data extracted from the ten records selected for this review according to reference, year of publication and country, population, type of study, level of evidence, and degree of recommendation.

All studies were published in 2020, with six studies carried out in China, two in the United States of America, one in the Netherlands and one in Switzerland, with NB patients aged 17 years old. Clinical findings, such as fever and affecting respiratory and/ or digestive systems, predominated, as well as evolution to cure through pharmacological and non-pharmacological treatments.

Concerning the classification of studies according to the level of evidence and degree of recommendation, the guidelines established by the Oxford Center for Evidence-Based Medicine were followed $^{(19)}$. It is highlighted that the lower the number, the greater the level of evidence of the study. Furthermore, degree of recommendation " $\mathrm{A}$ " is considered the one with the highest recommendation and " $D$ " the one with the lowest.

Chart 3 shows is a summary of the data extracted from the ten records selected for this review according to reference, clinical findings, treatment, and outcome.

Chart 2 - Documents included in the review according to reference, year of publication and country, population, type of study, level of evidence, and degree of recommendation, 2020

\begin{tabular}{|c|c|c|}
\hline Reference/Year of publication/Country & Population & $\begin{array}{l}\text { Type of Study/Level of evidence*/Degree of } \\
\text { recommendation* }\end{array}$ \\
\hline Chen et al ${ }^{(15)} / / 2020 /$ China. & Pediatric patients. & Ecological/2C/B. \\
\hline Hong et al (5) ./2020/Netherlands & NBs, infants and children. & Ecological/2C/B. \\
\hline Ji et $\mathrm{al}^{(20)} \cdot / 2020 /$ China & $\begin{array}{l}\text { Two pediatric patients ( } 1 \text { st with } 15 \text { years old and } \\
2 \text { nd with } 9 \text { years old). }\end{array}$ & Retrospective/3A/B. \\
\hline Chen et $\mathrm{al}^{(21)} \cdot / 2020 /$ China & 12 pediatric patients ( 7 months to 17 years). & Retrospective/3A/B. \\
\hline Qiu et al ${ }^{(22)} / / 2020 /$ United States of America & 36 pediatric patients ( 0 to 16 years). & Observational cohort/2B/B. \\
\hline Schwartz et al ${ }^{(23)} . / 2020 /$ Switzerland & One NB. & Ecological/2C/B. \\
\hline Shen et al ${ }^{(24)} / 2020 /$ China & 28 pediatric patients. & Editorial/5/D. \\
\hline Sun et $\mathrm{al}^{(25)} \cdot / 2020 /$ China & Eight severely ill or seriously ill pediatric patients. & Cohort/2B/B. \\
\hline Xia et $\mathrm{al}^{(26)} . / 2020 /$ United States of America & 20 pediatric patients. & Retrospective/3A/B. \\
\hline Zhu et al ${ }^{(27)} . / 2020 /$ China & 10 NBs of mothers infected by $2019-n C o V$. & Retrospective/3A/B. \\
\hline
\end{tabular}

Chart 3 - Synthesis of data extracted from documents included in the review according to reference, clinical findings, treatment, and outcome, 2020

\begin{tabular}{|c|c|c|c|}
\hline Reference & Clinical findings & Treatment & Outcome \\
\hline 15 & $\begin{array}{l}\text { Fever, fatigue, cough, nasal congestion, runny nose, sputum, } \\
\text { diarrhea, headache, dyspnea, cyanosis, malaise or restlessness, } \\
\text { poor diet, poor appetite and less activity. Decreased } \\
\text { lymphocyte count; increased C-Reactive Protein (CRP). Multiple } \\
\text { bilateral ground-glass opacity, infiltrating shadows and } \\
\text { pulmonary consolidation. }\end{array}$ & $\begin{array}{l}\text { Social isolation, adequate rest, } \\
\text { nutrition and hydration, antiviral } \\
\text { therapy (nebulization with interferon; } \\
\text { lopinavir/ritonavir), antibiotics, } \\
\text { immunomodulatory therapy (in severe } \\
\text { cases), respiratory support. }\end{array}$ & $\begin{array}{l}\text { No deaths reported in the } \\
\text { study. Pediatric patients } \\
\text { had good prognosis. }\end{array}$ \\
\hline 5 & $\begin{array}{l}\text { Fever, dry cough, fatigue, nasal congestion, runny nose, } \\
\text { abdominal discomfort, nausea, vomiting, abdominal pain, } \\
\text { and diarrhea. }\end{array}$ & $\begin{array}{l}\text { In NBs, suspected and confirmed cases } \\
\text { should be admitted to a neonatal ICU. } \\
\text { Treatment with antivirals; if respiratory } \\
\text { distress syndrome, administer pulmonary } \\
\text { surfactant, inhalation of nitric oxide and } \\
\text { high-frequency oscillatory ventilation. In } \\
\text { severe NBs, intravenous administration } \\
\text { of glucocorticoids or immunoglobulins } \\
\text { and sustainable renal replacement can } \\
\text { be considered. }\end{array}$ & Absent. \\
\hline
\end{tabular}




\begin{tabular}{|c|c|c|c|}
\hline Reference & Clinical findings & Treatment & Outcome \\
\hline 20 & $\begin{array}{l}\text { Fever, pharyngeal congestion and diarrhea. } \\
\text { High white blood cell count, high PCR. }\end{array}$ & $\begin{array}{l}\text { In the } 1 \text { st patient, symptomatic } \\
\text { treatment was used (study does not } \\
\text { describe treatment). In the } 2 \text { nd patient, } \\
\text { an oral probiotic was administered and } \\
\text { the symptoms disappeared after two } \\
\text { days of treatment. }\end{array}$ & $\begin{array}{l}\text { Patients were cured } \\
\text { without sequel. }\end{array}$ \\
\hline 21 & $\begin{array}{l}\text { Fever, cough, diarrhea, sore throat, nasal pain, dizziness, fatigue. } \\
\text { Leukopenia, lymphopenia, elevated CRP, higher amount of T } \\
\text { lymphocytes. Bilateral ground-glass opacities, irregular lung } \\
\text { shading. }\end{array}$ & $\begin{array}{l}\text { Treatment with antiviral drugs. } \\
\text { Inhalation therapy for interferon-a 1b, } \\
\text { Lopinavir/Ritonavir, Ribavirin. }\end{array}$ & $\begin{array}{l}\text { All patients relieve the } \\
\text { symptom } 3 \text { to } 4 \text { days after } \\
\text { admission to the hospital. } \\
\text { No case progressed to } \\
\text { severe. }\end{array}$ \\
\hline 22 & $\begin{array}{l}\text { Common symptoms: fever (36\%), dry cough (19\%), dyspnea or } \\
\text { tachypnea (3\%), pharyngeal congestion (3\%), sore throat (6\%), } \\
\text { vomiting or diarrhea (6\%), headache. } 30 \% \text { had pneumonia + } \\
\text { cough. } \\
53 \% \text { with pulmonary opacity (ground glass) on computed } \\
\text { tomography (CT). } \\
\text { Elevation of MB creatine kinase (31\%), decrease of lymphocytes } \\
(31 \%) \text {, leukopenia (19\%) and elevated procalcitonin. }\end{array}$ & $\begin{array}{l}\text { Upon admission, all children were } \\
\text { treated with alpha interferon by } \\
\text { aerosolization twice daily, } 14 \text { (39\%) } \\
\text { received lopinavir-ritonavir syrup twice } \\
\text { daily and six (17\%) required oxygen } \\
\text { inhalation. }\end{array}$ & $\begin{array}{l}\text { All } 36 \text { patients were cured } \\
\text { and discharged. }\end{array}$ \\
\hline 23 & Breathlessness, liver function and abnormal chest X-rays. & Treatment not described in the study. & Absent. \\
\hline 24 & $\begin{array}{l}\text { Fever, fatigue, dry cough, nasal congestion and runny nose } \\
\text { are reported as the most common symptoms. Although, less } \\
\text { common, nausea, vomiting and diarrhea can be mentioned. } \\
\text { Normal or slightly elevated PCR. Chest x-ray suggestive of } \\
\text { pneumonia. }\end{array}$ & $\begin{array}{l}\text { Alpha interferon atomization can be } \\
\text { considered as a treatment option for } \\
2019-n \text { CoV pneumonia. The safety and } \\
\text { effectiveness of using interferon still } \\
\text { needs confirmation. }\end{array}$ & $\begin{array}{l}\text { Patients with mild } \\
\text { symptoms recovered } \\
\text { within } 1-2 \text { weeks. Few } \\
\text { patients developed lower } \\
\text { respiratory tract infection. }\end{array}$ \\
\hline 25 & $\begin{array}{l}\text { Polypnea, fever, cough, sputum, nausea/vomiting, diarrhea, } \\
\text { fatigue/myalgia, headache, constipation, unilateral or } \\
\text { bilateral pneumonia, are more common symptoms. Adhesive } \\
\text { shadows, ground-glass opacity, pleural effusion, and white } \\
\text { alteration of the lung were also present in the alterations of } \\
\text { image exams. CRP, procalcitonin and lactate dehydrogenase } \\
\text { increased in more than half of patients. Main complications } \\
\text { were septic shock and multiple organ dysfunction } \\
\text { syndrome. Toxic encephalopathy, disseminated intravascular } \\
\text { coagulation, hydronephrosis, heart failure, among others, } \\
\text { have also been reported. }\end{array}$ & $\begin{array}{l}\text { Symptomatic treatment and respiratory } \\
\text { support. Most patients received high } \\
\text { flow oxygen therapy, two received } \\
\text { mechanical ventilation, all received } \\
\text { antiviral treatment with virazole, } \\
\text { oseltamivir and interferon. Antibiotics, } \\
\text { traditional Chinese medicine, } \\
\text { intravenous glucocorticoids and } \\
\text { immunoglobulin have also been used in } \\
\text { some cases. }\end{array}$ & $\begin{array}{l}5 \text { cures with hospital } \\
\text { discharge and } 3 \text { remained } \\
\text { hospitalized in ICUs. }\end{array}$ \\
\hline 26 & $\begin{array}{l}\text { Fever above } 37.3^{\circ} \mathrm{C} \text {, cough, diarrhea, nasal discharge, } \\
\text { vomiting, tachypnea, sore throat, fatigue, wet crackles and } \\
\text { signs of retraction were observed. Uni or bilateral pulmonary } \\
\text { lesions, subpleural lesions with localized inflammatory } \\
\text { infiltration, consolidation with surrounding halo, ground- } \\
\text { glass opacity, fine mesh shade and small nodules. Increase in } \\
\text { procalcitonin in } 80 \% \text { of cases and creatine kinase-MB in } 75 \% \text {. }\end{array}$ & $\begin{array}{l}\text { All patients were treated, but the study } \\
\text { does not specify the treatment. }\end{array}$ & $\begin{array}{l}18 \text { cures with hospital } \\
\text { discharge and two } \\
\text { remained hospitalized } \\
\text { under observation. }\end{array}$ \\
\hline 27 & $\begin{array}{l}\text { Shortness of breath (main symptom), fever, tachycardia, } \\
\text { vomiting, food intolerance, bloating, refusal of milk, gastric } \\
\text { bleeding and neonatal respiratory distress syndrome, } \\
\text { infections. } \\
\text { Abnormal chest radiography. } \\
\text { Complicated thrombocytopenia with abnormal liver function, } \\
\text { refractory shock, multiple organ failure, disseminated } \\
\text { intravascular coagulation and falling platelets. }\end{array}$ & $\begin{array}{l}\text { Symptomatic supportive treatment; } \\
\text { intravenous infusion of suspended } \\
\text { red blood cells, platelets and plasma; } \\
\text { respiratory support, intravenous } \\
\text { infusion of gamma globulin, } \\
\text { platelet transfusion, plasma, use of } \\
\text { hydrocortisone, low-dose sodium } \\
\text { heparin associated with low molecular } \\
\text { weight heparin calcium. }\end{array}$ & $\begin{array}{l}5 \text { cures with hospital } \\
\text { discharge, } 1 \text { death and } 4 \\
\text { remained hospitalized. }\end{array}$ \\
\hline
\end{tabular}

\section{DISCUSSION}

All scientific records were published in 2020, which indicates that the national scientific community needs to produce studies on such a disease due to a worldwide calamity and increasing mortality rate.

Among the clinical findings found in cases of the new COVID-19 infection, nasal congestion, fever, respiratory distress, diarrhea, fatigue, and dry cough stood out ${ }^{(22,28)}$. The ages of symptom onset reported in the studies range from zero to 17 years and the lethality rate for COVID-19 is lower when compared to SARS-CoV-2 and MERS-CoV. Pediatric patients have their own immune system and respond clinically to therapy differently from adults ${ }^{(15,25)}$.

According to a study conducted in Shenzhen, China, 138 cases of coronavirus infection were confirmed. Among this group, 15 were children and five had fever as a common symptom ${ }^{(28)}$. Thus, it is possible to identify that children have a smaller proportion in relation to the total number of infected ${ }^{(24)}$. It is also noted that the studies do not accurately portray the outcomes of the patients addressed in the research, leaving a gap with regard to hospital stay and recovery time. 
On the other hand, a cohort study carried out with 36 children, with an average age of 8.3 years, identified that about $53 \%$ children had a moderate clinical chart with signs of mild pneumonia, fever, cough, and fatigue; $47 \%$ of the mild type with symptoms prevalent in the upper airways (sore throat, runny nose and fever); $28 \%$ were asymptomatic (22).

Thus, it is possible to identify that there are differences between the symptoms manifested in children and adults, in most cases children have mild clinical manifestations or are asymptomatic ${ }^{(22,24)}$. Therefore, in several situations, in order to obtain a reliable diagnosis, suspected children need to undergo a risk classification to identify patients' epidemiological history combined with laboratory tests ${ }^{(22)}$.

As for diagnosis of infection by 2019-nCoV, the positive nasopharyngeal swab nucleic acid test is considered the gold standard. The other laboratory tests, despite not having high specificity and diagnostic power in children, can be used to rule out other diseases, as well as to perform dynamic monitoring to analyze worsening and progress of $\operatorname{cases}^{(29-30)}$. It was found that the main changes present in laboratory tests of neonatal and pediatric patients infected with COVID-19 are increased CRP(15,20-21,24-25), decreased white blood cells ${ }^{(21-22)}$, lymphopenia ${ }^{(15,21-22)}$, thrombocytopenia $^{(28)}$, increased procalcitonin ${ }^{(22,25-26)}$, increased creatine kinase $\mathrm{MB}^{(22,26)}$ and lactate dehydrogenase ${ }^{(27)}$.

Supporting the results of this research, a study carried out with 31 children infected with COVID-19 in six provinces in northern China, where all patients underwent laboratory tests, reveals that the majority obtained normal results. However, the laboratory changes detected and which contrast with this review were an increase in lymphocytes, an increase in white blood cells and thrombocytosis; similar findings were an increase in CRP, procalcitonin, lactate dehydrogenase and creatine kinase MB. Despite not having high specificity and diagnostic power in children, the other laboratory tests can be used to rule out other diseases, as well as perform patient dynamic monitoring ${ }^{(30)}$.

In addition to laboratory findings, imaging tests are also essential diagnostic methods to detect the disease and monitor the evolution of patients' clinical conditions. Among the different types of exams, CT and chest radiography use stands out as the most effective to show the presence of possible changes by coronavirus. The studies showed the following findings: bilateral ground-glass opacity ${ }^{(15,21-22,25-26)}$, pulmonary consolidation ${ }^{(15,21,26)}$, pulmonary and subpleural lesions ${ }^{(26)}$, abnormal chest radiographs suggestive of pneumonia(23-24,27), pleural effusion ${ }^{(25)}$, white spots on the lung ${ }^{(25)}$ and small nodules ${ }^{(26)}$.

One of the selected records $s^{(25)}$, with the best level of evidence and degree of recommendation in this review (cohort study-2B/B), which exemplifies this situation, is the research carried out with eight critically ill children (patients' age ranged from two months 15 years) infected by COVID-19 who were admitted to an ICU at Children's Hospital in Wuhan-China. All patients had abnormalities on chest X-ray or CT scans, with the following changes being evident: multiple adhesive-shaped shadows (7/8), ground-glass opacity (6/8), pleural effusion (1/8) and white spots on the lung (1/8). In addition to these findings, other updated research on this topic reinforces this information, showing results of imaging studies with the presence of pulmonary consolidation, presence of a halo at the edges, increased texture in both lungs, shadows and irregular ground-glass nodules, lung lesions, and subpleural (29-33).

As the main forms of treatment of 2019-nCoV in neonates and children, studies include the use of antivirals ${ }^{(5,15,21-22,25)}$, respiratory support ${ }^{(5,15,22,25,27)}$, immunomodulatory therapy ${ }^{(5,15,25,27)}$, symptomatic treatment ${ }^{(20,25,27)}$, glucocorticoids ${ }^{(5,25)}$, antibiotics ${ }^{(15,25)}$ and alpha interferon ${ }^{(22,24)}$. However, other strategies such as social isolation, rest, adequate nutrition and hydration ${ }^{(15)}$, pulmonary surfactant, nitric oxide inhalation ${ }^{(5)}$, oral probiotic ${ }^{(20)}$, traditional Chinese medicine ${ }^{(25)}$, infusion of red blood cells, platelets and plasma, use of hydrocortisone and association of low-dose sodium heparin with low molecular weight calcium heparin ${ }^{(27)}$ were also cited.

In line with the aforementioned authors, a retrospective study was carried out with the registration of all children aged 1 month to 14 years old, admitted by COVID-19, in ten public hospitals in Wuhan. In their results, among other evidences, the clinical treatment of these children was evidenced. The treatment carried out involved quarantine in the hospital, $48 \%$ received antiviral therapy mainly with interferon, $56 \%$ received empirical antibiotics, $8 \%$ were critical cases and received invasive mechanical ventilation, corticosteroids and immunoglobulin. In a critical case, renal replacement therapy has been reported. One patient was discharged and $96 \%$ had their symptoms relieved ${ }^{(34)}$.

In view of the main clinical findings and their treatments, it was necessary to highlight the outcomes of these patients in order to understand the path and severity of the disease. Most studies

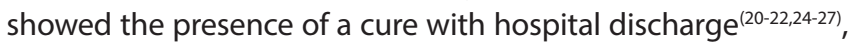
three studies showed the permanence in inpatient units ${ }^{(25-27)}$, one study brought the lower respiratory tract infection ${ }^{(23)}$, one presented death $^{(27)}$ and two studies showed a good prognosis ${ }^{(15,21)}$ as outcomes. However, two studies did not have this information described ${ }^{(5,23)}$.

A study carried out in Hubei province reports a case of a three-month-old baby infected with coronavirus. The child was admitted to the hospital with fever for four hours, presenting $38^{\circ} \mathrm{C}$. On the chest radiography, a right lung with a thicker texture and a part of shadow was admitted, and samples were collected for the detection of 2019-nCoV. Azithromycin and ceftazidime were used to treat symptomatic and fight infections. The following day, the temperature was normalized, new samples were collected which were positive for the virus. On the third day, the child developed symptoms such as cough, was treated with ambruterol and nebulization, among others, for symptom relief. On the fourth day, new pharyngeal samples were collected and have been negative since then for the next ten days. Only the stool sample was positive for the virus. The child was discharged after 15 days $^{(35)}$.

\section{Study limitations}

Sample size limitations were evident, even when searching eight databases, for the reason that it was an infection that appeared in December 2019 and due to the scarcity of studies aimed at the neopediatric population. For this reason, it would be important to conduct more scientific research aimed at nursing care for neonatal and pediatric patients with COVID-19.

It is noteworthy that all studies were published in 2020 and in countries abroad, reinforcing the need for publications at national 
level. Patients' ages ranged from 0 to 17 years. When compared to adults, children have mild or asymptomatic clinical manifestations. It was also observed that the main laboratory changes were the increase in CRP, leukopenia, lymphopenia and increased procalcitonin; alterations in imaging studies were bilateral ground-glass opacity, pulmonary consolidation and abnormal radiography. The most used treatments were the use of antivirals, immunomodulatory therapy and respiratory support. Most of the selected studies showed the presence of a cure with patients' discharge.

It is observed that there is a lack of theoretical references that present studies with a better level of evidence and degree of recommendation regarding the evolution of cases of COVID-19 infection in neonatal and pediatric patients. This can be justified because it is a subject hitherto recent in the literature, it is clear that there is a limitation of scientific knowledge in this given area of knowledge, raising the need for systematic research on this theme.

\section{Contributions to nursing, health, and public policy}

Carrying out this review contributes significantly to the scientific growth in the neonatal and pediatric health field by analyzing the evolution of cases of COVID-19 infection, considering the current pandemic scenario, enabling a greater basis and improvement of care provided, show forms of treatment and outcomes.

Nursing plays a fundamental role in the current scenario we are facing, as it is a profession with professionals working on the front line of the pandemic, being the first to provide assistance to patients. The study's findings reinforce the need to map knowledge about the clinical evolution of neopediatric patients with COVID-19, highlighting their main clinical findings, treatment and outcome, in order to favor health professionals with comprehensive and resolute care in this population.

\section{FINAL CONSIDERATIONS}

From analysis of the evolution of cases of COVID-19 infection in neonatal and pediatric patients, it was possible to identify that the most affected study population varies between the age of zero to 17 years. It was also evident that the main clinical complications found were nasal congestion, fever, respiratory distress, diarrhea, fatigue, and dry cough. When compared to adults, children have mild or asymptomatic clinical manifestations.

It was also observed that the main laboratory changes were the increase in CRP, leukopenia, lymphopenia and increased procalcitonin; alterations in imaging studies were bilateral ground-glass opacity, pulmonary consolidation and abnormal radiography. The most used treatments were the use of antivirals, immunomodulatory therapy and respiratory support. Most of the selected studies showed the presence of a cure with patients' discharge.

Therefore, we hope that this analysis of the evolution of cases of COVID-19 infection in neonatal and pediatric patients will motivate further studies to analyze the impact of this disease and its complications at the national level, as well as to conduct more scientific research aimed at assistance care for infected neonatal and pediatric patients. The present study provided a greater scientific basis and improved care by showing forms of treatment and outcomes.

\section{REFERENCES}

1. Hui DS, Azhar El, Madani TA, Ntoumi F, Kock R, Dar O, et al. The continuing 2019-nCoV epidemic threat of novel coronaviruses to global health: the latest 2019 novel coronavirus outbreak in Wuhan, China. Int J Infect Dis. 2020;91:264-66. doi: 10.1016/j.ijid.2020.01.009

2. Zhu N, Zhang D, Wang W, Li X, Yang B, Song J, et al. A novel coronavirus from patients with pneumonia in China, 2019. N Engl J Med. 2020; 382(8):727-33. doi: 10.1056/NEJMoa2001017

3. Gorbalenya AE, Baker SC, Baric SR, Groot RJ, Drosten C, Gulyaeva AA, et al. The species Severe acute respiratory syndrome-related coronavirus: classifying 2019-nCoV and naming it SARS-CoV-2. Nat Microbiol. 2020;5(4):536-44. doi: 10.1038/s41564-020-0695-z

4. letto G. SARS - CoV-2: Reasons of epidemiology of severe ill disease cases and therapeutic approach using trivalent vaccine (tetanus, diphtheria and Bordetella pertussis). Med Hypotheses. 2020;141:109779. doi: 10.1016/j.mehy.2020.109779

5. Hong H, Wang Y, Chung H, Chen C. Clinical characteristics of novel coronavirus disease 2019 (COVID-19) in newborns, infants and children. PEDN. 2020;61(2)131-2. doi: 10.1016/j.pedneo.2020.03.001

6. Shen $\mathrm{K}$, Yang $\mathrm{Y}$, Wang T, Zhao D, Jiang Y, Jin R, et al. Diagnosis, treatment, and prevention of 2019 novel coronavirus infection in children: experts' consensus statement. World J Pediatr. 2020;1-9. doi: 10.1007/s12519-020-00343-7

7. Shereen MA, Khan S, Kazmi A, Bashir N, Siddique R. COVID-19 infection: Origin, transmission, and characteristics of human coronaviruses. J Adv Res. 2020;24:91-8. doi: 10.1016/j.jare.2020.03.005

8. Zhou M, Zhang X, Qu J. Coronavirus disease 2019 (COVID-19): a clinical update. Front Med. 2020; 1-10. doi: 10.1007/s11684-020-0767-8

9. Bai Y, Yao L, Wei T, Tian F, Jin D, Chen L, et al. Presumed asymptomatic carrier transmission of COVID-19. JAMA. 2020;323(14):1406-7. doi: 10.1001/jama.2020.2565

10. Oliveira AC, Lucas TC, lquiapaza RA. What has the Covid-19 pandemic taught us about adopting preventive measures? Texto Contexto Enferm. 2020;29:e20200106. doi: 10.1590/1980-265X-TCE-2020-0106

11. Matsuno AK, Gagliardi TB, Paula FE, Luna LKS, Jesus BLS, Stein RT, et al. Human coronavirus alone or in co-infection with rhinovirus C is a risk factor for severe respiratory disease and admission to the pediatric intensive care unit: a one-year study in Southeast Brazil. PLoS One. 2019;14(6):1-9. doi: 10.1371/journal.pone.0217744 
12. Ortiz-Hernández AA, Nishimura KK, Noyola DE, Espinosa SM, Gamiño A, Fraga AG, et al. Differential risk of hospitalization among single virus infections causing influenza-like illnesses. Influenza Other Respir Viruses. 2019;13(1):36-43. doi: https://doi.org/10.1111/irv.12606

13. Bartenfeld M, Griese S, Uyeki T, Gerber S, Peacock G. Middle East Respiratory Syndrome Coronavirus and Children: what pediatric health care professionals need to know, 2017. Clin Pediatr. 2017;56(2):187-9. doi: 10.1177/0009922816678820

14. Chen H, Guo J, Wang C, Luo F, Yu X, Zhang W, et al. Clinical characteristics and intrauterine vertical transmission potential of COVID-19 infection in nine pregnant women: a retrospective review of medical records. Lancet. 2020;395(10226):809-15. doi: 10.1016/ S0140-6736(20)30360-3

15. Chen ZM, Fu JF, Shu Q, Chen YH, Hua CZ, Li FB, et al. Diagnosis and treatment recommendations for pediatric respiratory infection caused by the 2019 novel coronavirus. World J Pediatr. 2020;1-7. doi: 10.1007/s12519-020-00345-5

16. Peters MDJ, Godfrey C, McInerney P, Munn Z, Tricco AC, Khalil H. Chapter 11: Scoping Reviews (2020 version). In: Aromataris E, Munn Z (Editors). Joanna Briggs Institute Reviewer's Manual, JBI [Internet]. 2020 [cited 2020 Apr 02]. Available from: https://reviewersmanual. joannabriggs.org/

17. Moher D, Liberati A, Tetzlaff J, Altman DG. Preferred Reporting Items for Systematic Reviews and Meta-Analyses: The PRISMA Statement. PLoS Med. 2009;6(7):e1000097. doi: 10.1371/journal.pmed1000097

18. Costa TMS, Santos KVG, Rocha RRA, Oliveira ES, Dantas RAN, Dantas DV. Evolução clínica dos casos de infecção por COVID-19 em neopediatria: scoping review [Internet]. 2020 [cited 2020 Jun 12]. Available from: https://osf.io/et4p8

19. Centre for Evidence-Based Medicine. Levels of Evidence (March 2009) [Internet]. 2009 [cited 2020 Apr 02]. Available from: https://www. cebm.net/2009/06/oxford-centre-evidence-based-medicine-levels-evidence-march-2009/

20. Ji LN, Chao S, Wang YJ, Li XJ, Mu XD, Lin MG, et al. Clinical features of pediatric patients with COVID-19: a report of two family cluster cases. World J Pediatr. 2020; 1-4. doi: 10.1007/s12519-020-00356-2

21. Chen J, Zhang ZZ, Chen YK, Long QX, Tian WG, Deng HJ, et al. The clinical and immunological features of pediatric COVID-19 patients in China. Genes Dis. 2020;1-7. doi: 10.1016/j.gendis.2020.03.008

22. Qui H, Wu J, Hong L, Luo Y, Song Q, Chen D. Clinical and epidemiological features of 36 children with coronavirus disease 2019 (COVID-19) in Zhejiang, China: an observational cohort study. Lancet Infect Dis. 2020;1-8. doi: 10.1016/S1473-3099(20)30198-5

23. Schwartz DA, Graham AL. Potential Maternal and Infant Outcomes from Coronavirus 2019-nCoV (SARS-CoV-2) Infecting Pregnant Women: Lessons from SARS, MERS, and Other Human Coronavirus Infections. Viruses. 2020;12(2):1-16. doi: 10.3390/v12020194

24. Shen KL, Yang YH. Diagnosis and treatment of 2019 novel coronavirus infection in children: a pressing issue. World J Pediatr. 2020;1-3. doi: 10.1007/s12519-020-00344-6

25. Sun D, Li H, Lu XX, Xiao H, Ren J, Zhang FR, et al. Clinical features of severe pediatric patients with coronavirus disease 2019 in Wuhan: a single center's observational study. World J Pediatr. 2020;1-9. doi: 10.1007/s12519-020-00354-4

26. Xia W, Shao J, Guo Y, Peng X, Li Z, Hu D. Clinical and CT features in pediatric patients with COVID-19 infection: different points from adults. Pediatr Pulmonol. 2020;55(5):1-6. doi: 10.1002/ppul.24718

27. Zhu H, Wang L, Fang C, Peng S, Zhang L, Chang G, et al. Clinical analysis of 10 neonates born to mothers with 2019-nCoV pneumonia. Transl Pediatr. 2020;9(1):51-60. doi: 10.21037/tp.2020.02.06

28. Wang D, Hu B, Hu C, Zhu F, Liu X, Zhang J, et al. Clinical Characteristics of 138 Hospitalized Patients With 2019 Novel Coronavirus-Infected Pneumonia in Wuhan, China. JAMA. 2020;323(11):1061-69. doi: 10.1001/jama.2020.1585

29. Feng K, Yun YX, Wang XF, Yang GD, Zheng YJ, Lin CM, et al. Analysis of CT features of 15 Children with 2019 novel coronavirus infection. CJP. 2020;58(0):E00758. doi: 10.3760/cma.j.issn.0578-1310.2020.0007

30. Wang D, Ju XL, Xie F, Lu Y, Li FY, Huang HH, et al. Clinical analysis of 31 cases of 2019 novel coronavirus infection in children from six provinces (autonomous region) of northern China. CJP. 2020; 58(4):E011. doi: 10.3760/cma.j.cn112140-20200225-00138

31. Su L, Ma X, Yu H, Zhang Z, Bian P, Han Y, et al. The different clinical characteristics of coronavirus disease cases between children and their families in China - the character of children with COVID-19. Emerg Microbes Infect. 2020;9(1):707-13. doi: 10.1080/22221751.2020.1744483

32. Cai JH, Wang XS, Ge YL, Xia AM, Chang HL, Tian H, et al. First case of 2019 novel coronavirus infection in children in Shanghai. CJP. 2020;58(2):86-7. doi: 10.3760/cma.j.issn.0578-1310.2020.02.002

33. Chen F, Liu ZS, Zhang FR, Xiong RH, Chen Y, Cheng XF, et al. First case of severe childhood novel coronavirus pneumonia in China. CJP. 2020; 58(0):E005. doi: 10.3760/cma.j.issn.0578-1310.2020.0005

34. Zheng F, Liao C, Fan Q-H, Chen H-B, Zhao X-G, Xie Z-G, et al. Clinical Characteristics of Children with Coronavirus Disease 2019 in Hubei, China. Curr Med Sci. 2020;40(2):275-80. doi: 10.1007/s11596-020-2172-6

35. Zhang YH, Lin DJ, Xiao MF, Wang JC, Wei Y, Lei ZX, et al. 2019-novel coronavirus infection in a three-month-old baby. Chin J Pediatr. 2020;58(0):E006. doi: 10.3760/cma.j.issn.0578-1310.2020.0006 